\title{
ANALISIS DAMPAK KETIMPANGAN PERTUMBUHAN EKONOMI WILAYAH TERHADAP KEMISKINAN DI WILAYAH BARAT SELATAN PROVINSI ACEH
}

(Analisis Of Impact Ekonomic Growth Areas On Povertyn The South West Territory Of Aceh Province)

\author{
Yuwanda Irmiyanti ${ }^{1}$, T Fauzi $^{1}$, Suyanti Kasimin ${ }^{1 *}$ \\ ${ }^{1}$ Program Studi Agribisnis, Fakultas Pertanian, Universitas Syiah Kuala
}

\begin{abstract}
Abstrak. Kesejahteraan suatu wilayah dapat di lihat dari besarnya PDRB per kapita serta peran sektor-sektor di dalamnya sehingga menghasilkan pertumbuhan ekonomi yang tinggi di setiap daerah. Tujuan dari penelitian ini adalah untuk menganalisis dampak ketimpangan pertumbuhan ekonomi wilayah terhadap kemiskinan di Wilayah Barat Selatan Provinsi Aceh yang di lihat dari tingkat PDRB per kapita. Tingkat ketimpangan pertumbuhan ekonomi di analisis dengan menggunakan ukuran koefisien variasi dari logaritma PDRB atas harga konstan 2000 dan koefisien variasi dari masing-masing variabel pertumbuhan penduduk serta kontribusi sektor industri. Adapun tingkat kecenderungan ketimpangan pertumbuhan ekonomi dianalisis secara deskriptif menggunakan rumus Indeks Williamson. Hasil dari analisis menunjukkan perekonomian di 5 Kabupaten Wilayah Barat Selatan Provinsi Aceh selama kurun waktu 2009-2015 mengalami tingkat ketimpangan sedang sampai dengan tingggi (IW 0,38-0,62). Dari 2 variabel yang di duga mempengaruhi ketimpanganpertumbuhanekonomi wilayah maka faktor yang signifikan adalah faktor kontribusi sektor industri, sedangkan faktor pertumbuhan penduduk tidak berpengaruh terhadap ketimpangan pertumbuhan ekonomi wilayah. Hal ini disebabkan oleh penyerapan tenaga kerja yang masih tinggi. Hasil penelitian ini juga di simpulkan bahwa bahwa semakin tinggi ketimpangan pertumbuhan ekonomi wilayah maka akan berdampak pada tingginya persentase penduduk miskin di masingmasing wilayah.
\end{abstract}

Kata Kunci : Ketimpangan Pertumbuhan Ekonomi, Fator-faktor Ketimpangan, Indeks Williamson.

\begin{abstract}
Welfare of a area can be seen from the size of GRDP per capita and the role of sectors in it so as to produce high economic growth in each region. The purpose of this study is to analyze the impact of regional economic growth inequality on poverty in the South West Region of Aceh Province viewed from the level of GRDP per capita. The level of inequality of economic growth in the analysis by using the size of the coefficient of variation of the GDP logarithm over 2000 constant prices and the coefficient of variation of each variable of population growth as well as the contribution of the industrial sector. The level of trends inequality of economic growth is analyzed descriptively using Williamson Index formula. The results of the analysis showed that the economy in 5 Districts of the Western Region of Aceh Province during the period of 2009-2015 experienced a low level of moderate to high (IW 0,38-0,62). From 2 variables which is to be expected affect the imbalance of regional economic growth then a significant factor is the contribution factor of the industrial sector, while the population growth factor does not affect the imbalance of regional economic growth. This is due to the high employment absorption. The results of this study also concluded that the high inequality of regional economic growth will affect the high percentage of poor people in each region.
\end{abstract}

Key Words: Economic Growth Inequality, Inequality Factors, Williamson Index.

\section{PENDAHULUAN}

Provinsi Aceh terdiri dari 23 kabupaten serta 5.001,95 ribu penduduk dengan luas wilayah sebesar 5.677.081 ha. Salah satu masalah yang dihadapi Provinsi Aceh adalah ketimpangan pertumbuhan ekonomi antar wilayah dan kemiskinan. Ketimpangan dapat terjadi karena salah satu faktor seperti pemerintah yang lebih aktif didalam membangun wilayah perkotaan. Pertumbuhan ekonomi merupakan salah satu indikator yang berperan mempengaruhi pembangunan ekonomi di suatu wilayah. Dimana pembangunan ekonomi suatu wilayah dapat diukur melalui Produk Domestik Regional Bruto (PDRB) yang dapat mencerminkan tingkatkesejahteraan masyarakat. Pembangunan nasional merupakan pembangunan dari oleh dan untuk rakyat yang di laksanakan di semua aspek kehidupan

*Corresponding author: suyantikasimin@unsyiah.ac.id 
bangsa dan di arahkan untuk mencapai kemajuan serta kesejahteraan masyarakat. Wilayah Barat Selatan Provinsi Aceh merupakan wilayah yang terdiri dari 8 kabupaten yaitu Kabupaten Aceh Jaya, Kabupaten Aceh Barat, Kabupaten Nagan Raya, Kabupaten Aceh Barat Daya, Kabupaten Aceh Selatan, Kabupaten Simeulu, Kabupaten Aceh Singkil dan Kota Subulussalam. Masing-masing kabupaten ini memiliki karakteristik sumberdaya yang berbeda guna meningkatkan pertumbuhan ekonominya. Menurut Sukirno (2004), salah satu alat untuk mengukur keberhasilan perekonomian suatu wilayah adalah pertumbuhan ekonomi wilayah itu sendiri. Perekonomian pada suatu wilayah akan mengalami kenaikan dari tahun ketahun dikarenakan adanya penambahan pada faktor produksi. Berikut merupakan pertumbuhan ekonomi Provinsi Aceh 4 tahun terakhir yaitu:

Tabel 1: Pertumbuhan Ekonomi (\%) Provinsi Aceh tahun 2012-2015.

\begin{tabular}{|l|c|r|}
\hline \multicolumn{1}{|c|}{ No. } & PertumbuhanEkonomi (\%) & $\begin{array}{c}\text { JumlahPendudukMiskin } \\
\text { (RibuJiwa) }\end{array}$ \\
\hline 2012 & $5,0 \%$ & 909,04 \\
\hline 2013 & $4,2 \%$ & 840,70 \\
\hline 2014 & $4,0 \%$ & 881,26 \\
\hline 2015 & $4,3 \%$ & 851,59 \\
\hline Rata-rata & $4,4 \%$ & 870,65 \\
\hline
\end{tabular}

Sumber: BPS Provinsi Aceh 2016

Tabel di atas dapat di lihatbahwa rata-rata pertumbuhan ekonomi di Provinsi Aceh dari tahun 2012 sampai dengan tahun 2015 yaitu sebesar 4,4\%. Pertumbuhan ekonomi Provinsi Aceh pada tahun penelitian mengalami fluktuasi, pertumbuhan ekonomi tertinggi terjadi pada tahun 2012 yaitu sebesar 5,0\%, sedangkan pertumbuhan ekonomi terendah tejadi pada tahun 2014 yaitu sebesar 4,0\%. Pertumbuhan ekonomi di Provinsi Aceh selalu mengalami fluktuasi, akan tetapi pada tahun 2015 pertumbuhan ekonomi kembali meningkat meskipun peningkatannya di bawah tahun 2012 yaitu sebesar 4,3\%. Jika dilihat dari jumlah penduduk miskin, fluktuasi di ikuti oleh pertambahan jumlah penduduk miskin. Hal ini terlihat dari peningkatan dan penurunan jumlah penduduk miskin yang ada di Provinsi Aceh dari tahun 2012 sampai dengan 2015. Berdasarkan angka yang di peroleh dari BPS Provinsi Aceh, jumlah penduduk miskin tertinggi terjadi pada tahun 2012 yaitu sebesar 904,04 ribu jiwa, sedangkan jumlah penduduk terendah terdapat pada tahun 2012 yaitu sebesar 840,70 ribu jiwa. Sedangkan tara-rata jumlah penduduk miskin dalam 4 tahun terakhir yaitu sebesar 870,65 ribu jiwa.

Pertumbuhan ekonomi yang semakin membaik masih meninggalkan permasalahan yang harus dihadapi oleh Pemerintah Provinsi Aceh. Salah satu permasalahan yang di hadapi adalah kemiskinan, realitas pertumbuhan ekonomi di 5 kabupaten yang ada di bagian Barat Selatan Provinsi Aceh ini tentunya di akibatkan oleh adanya perbedaan laju pertumbuhan sehingga menyebabkan terciptanya kesenjangan dan kemiskinan antar kabupaten/kota. Ketimpangan pertumbuhan ekonomi kerap terjadi di daerah yang baru berkembang seperti di Kabupaten Aceh Jaya, Kabupaten Nagan Raya dan Kabupaten Aceh Barat Daya. Secara umum ketimpangan pertumbuhan ekonomi wilayah memiliki dampak positif dan dampak negatif. Dampak positif ketimpangan pertumbuhan ekonomi wilayah yaitu dapat mendorong daerah yang kurang maju untuk dapat bersaing dan meningkatkan pertumbuhan ekonomi guna meningkatkan kesejahteraan wilayahnya.Sedangkan dampak negative dari ketimpangan pertumbuhan ekonomi yang ekstrim yaitu inefisiensi ekonomi, melemahkan stabilitas social

Analisis Dampak Ketimpangan Pertumbuhan Ekonomi Wilayah Terhadap Kemiskinan Di Wilayah Barat Selatan Provinsi Aceh (Yuwanda Irmiyanti, Suyanti Kasimin, T. Fauzi) 
dan solidaritas, serta ketimpangan yang tinggi pada umumnya dipandang tidakadi 1(Todaro, 2006).

Keterbatasan sektor industri sebagai penunjang kinerja ekonomi daerah yang dilihat dari jumlah kontribusi sekto rindustri terhadap PDRB sebagai pendukung kehidupan berimplikasi munculnya wilayah yang tertinggal. Beberapa fakta kesenjangan tersebut tercermin dalam kesenjangan kinerja pertumbuhan perekonomian antara kabupaten/kota di Wilayah Barat Selatan Provinsi Aceh sehingga berdampak kepada kesejahteraan masyarakat wilayah tersebut. Selainitu, ketimpangan pertumbuhan ekonomi wilayah juga timbul dikarenakan tidak adanya pemerataan dalam pembangunan ekonomi. Hal ini terlihat dengan adanya wilayah yang maju dengan wilayah yang terkebelakang atau kurangmaju. Ketidak merataan pembangunan ini di sebabkan karena adanya perbedaan antara wilayah satu dengan lainnya. Salah satu permasalahan ketimpangan yang menonjol khususnya di Provinsi Aceh adalah kesenjangan antar daerah sebagai konsekuensi dari terkonsentrasinya kegiatan perekonomian di wilayah yang lebih dulu maju. Berkembangnya kabupaten-kabupaten barusejak tahun 2002 dan desentralisasi diduga akan mendorong kesenjangan antar daerah yang lebih lebar (Ginting, 2013). Melihat kondisi tersebut, maka penulis tertarik ingin meneliti tentang dampak dari ketimpangan pertumbuhan ekonomi terhadap kemiskinan, penelitian ini mengangkat judul penelitian "Analisis Dampak Ketimpangan Pertumbuhan Ekonomi Wilayah Terhadap Kemiskinan di Wilayah Barat Selatan Provinsi Aceh". Adapun tujuan dari penelitian ini adalah untuk menganalisis tingkat ketimpangan pertumbuhan ekonomi wilayah, mengetahui pengaruh faktor pertumbuhan penduduk dan kontribusi sektor industri terhadap ketimpangan pertumbuhan ekonomi wilayah dan mengetahui bagaimana hubungan ketimpangan pertumbuhan ekonomi wilayah terhadap kemiskinan di wilayah Barat Selatan Provinsi Aceh.

\section{METODE PENELITIAN}

Penelitian ini dilakukan di lima kabupaten yang ada di Wilayah Barat Selatan Provinsi Aceh yaitu Kabupaten Aceh Jaya, Aceh Barat, Nagan Raya, Aceh Barat Daya dan Kabupaten Aceh Selatan. Penelitian ini juga dilaksanakan pada tahun 2016 sampai dengan tahun 2017 dengan tahun objek dalam penelitian yaitu pada tahun 2009 sampai dengan tahun 2015.

\section{Objek dan Ruang Lingkup Penelitian}

Objek penelitian ini adalah PDRB atas dasar harga konstan, kontibusi sektor industri, jumlah penduduk dan jumlah penduduk miskin yang ada di lima Kabupaten Barat Selatan Provinsi Aceh. Ruang lingkup penelitian ini terbatas pada masalah analisis ketimpangan wilayah dan faktor-faktor yang mempengaruhi ketimpangan, serta dampaknya terhadap kemiskinan di Wilayah Barat Selatan Provinsi Aceh.

\section{Metode Analisis}

1. Analisis Ketimpangan Indeks Williamson

Indeks ini digunakan untuk mengukur penyebaran (dispersi) tingkat pendapatan perkapita daerah relatif terhadap rata-rata nasional, yang merupakan ukuran ketimpangan pembangunan yang pertama kali ditemukan oleh Jeffrey G. Williamson dalam studinya pada tahun 1966. Berbeda dengan gini rasio yang sering digunakan untuk mengukur distribusi pendapatan, Indeks Williamson menggunakan PDRB perkapita sebagai data dasar karena yang 
di perbandingkan adalah tingkat pembangunan antar wilayah dan bukan tingkat kemakmuran antar kelompok. Secara statistik formulasinya (Sjafrizal, 2008) dalam (Mopangga, 2011) adalah sebagai berikut:

Dimana:

$$
I W=\frac{1}{\bar{y}} \sqrt{\sum_{i=1}^{n}\left(y_{i}-\bar{y}\right)^{2}} \frac{P i}{P}
$$

IW = Indeks Williamson

$\mathrm{y}_{\mathrm{i}} \quad=$ Pendapatan kecamatan /kota $\mathrm{i}$

$\overline{\mathrm{y}} \quad=$ PDRB Perkapita di kabupaten/kota

$\mathrm{P}_{\mathrm{i}} \quad=$ Jumlah Penduduk di kecamatan $/$ kota $\mathrm{i}$

$\mathrm{P} \quad=$ Jumlah penduduk di kabupaten/kota

Indeks Williamson besarnya antara nol dan satu, semakin kecil angka yang dihasilkan menunjukkan ketimpangan yang semakin kecil pula atau dapat dikatakan semakin merata. Tetapi jika angka yang didapat mendekati satu maka ketimpangan semakin lebar. Oshima dalam Matolla (1985) menetapkan sebuah kriteria yang digunakan untuk menentukan tingkat ketimpangan taraf rendah, sedang atau tinggi. Kriteria yang digunakan adalah sebagai berikut:

a. Ketimpangan taraf rendah, bila indeks ketimpangan kurang dari 0,35

b. Ketimpangan taraf sedang, bila indeks ketimpangan antara 0,35 -0,50

c. Ketimpangan taraf tinggi, bila indeks ketimpangan lebih dari 0,50

2. Analisis Faktor-faktor yang Mempengaruhi Ketimpangan

Persamaan yang memperlihatkan sejauh mana variabel-variabel sumber daya alam, angkatan kerja dan angka melek huruf mempengaruhi pertumbuhan ekonomi di Wilayah Barat Selatan Provinsi Aceh. Secara matematis, hubungan antar variabel-variabel yangdi gunakan untuk menganalisis ketimpangan pertumbuhan ekonomi terhadap kemiskinan di gambarkan dalam fungsi double log sebagaiberikut:

Adapun bentuk model ekonometrikanya adalah sebagai berikut (Gujarati, 1978):

$$
y=\beta_{0}+\beta_{1} X_{1}+\beta_{2} X_{2}+\varepsilon
$$

keterangan:

$\begin{array}{ll}\mathrm{Y} & =\text { Ketimpangan pertumbuhan ekonomi wilayah } \\ \mathrm{X} 1 & =\text { Pertumbuhan Penduduk tahun 2009-2015 } \\ \mathrm{X} 2 & =\text { Kontribusi Sektor Industri terhadap PDRB tahun 2009-2015 } \\ \text { B0 } & =\text { konstanta } \\ \text { B1, B2 } & =\text { parameter } \\ \mathrm{e} & =\text { residual error }\end{array}$

\section{Luas Wilayah Kabupaten}

\section{HASIL DAN PEMBAHASAN}

Karakteristik suatu wilayah tercermin dari luas masing-masing suatu wilayah di lima Kabupaten Barat Selatan Provinsi Aceh yaitu Kabupaten Aceh Jaya, Kabupaten Aceh Barat, Kabupaten Nagan Raya, Kabupaten Aceh Barat Daya dan Kabupaten Aceh Selatan dengan pertimbangan daerah ini mempunyai potensi yang besar dalam subsektor pertanian dan industri baik dalam sektor pemanfaatannya maupun untuk dikembangkan sehingga 
memberikan kontribusi yang tinggi terhadap peningkatan pertumbuhan ekonomi daerah. Berdasarkan data yang terdapat pada penelitian ini, luas wilayah masing-masing kabupaten serta persentase luas wilayah masing-masing kabupaten dapat di lihat pada tabel berikut:

Tabel 2. Luas Wialaya 5 kabupaten di Wilayah Barat Selatan Aceh.

\begin{tabular}{|c|l|r|r|}
\hline No. & \multicolumn{1}{|c|}{ Kabupaten } & Luas Wilayah $(\mathrm{Km})$ & \multicolumn{1}{c|}{ Persentase (\%) } \\
\hline 1. & Aceh Jaya & 3.813 & $6,58 \%$ \\
\hline 2. & Aceh Barat & $2.927,95$ & $5,05 \%$ \\
\hline 3. & Nagan Raya & $3.363,72$ & $5,80 \%$ \\
\hline 4. & Aceh Barat Daya & $1.490,60$ & $2,57 \%$ \\
\hline 5. & Aceh Selatan & $3.841,60$ & $6,63 \%$ \\
\hline \multicolumn{2}{|c|}{ Jumlah } & 15.437 & $5,33 \%$ \\
\hline
\end{tabular}

Sumber: BPS Provinsi Aceh tahun 2016.

Dari gambar di atas dapat dilihat bahwa wilayah yang memiliki luas terbesar adalah Kabupaten Aceh Selatan dengan luas wilayah yaitu sebesar 3.841,60 $\mathrm{Km}^{2}$ atau sekitar 6,63\%. Sedangkan kabupaten dengan luas wilayah terkecil terdapat di Kabupaten Aceh Barat Daya dengan luas sebesar 1.490,60 $\mathrm{Km}^{2}$ atau sebesar 2,57 \% dari $15.437 \mathrm{Km}^{2}$.

\section{Keadaan Penduduk}

Wilayah Barat Selatan Provinsi Aceh merupakan daerah yang terbuka dimana penduduk yang mendiami wilayah ini sangat heterogen yang terdiri dari berbagai suku. Mayoritas penduduk Wilayah Barat Selatan Provinsi Aceh adalah penduduk asli Aceh, selebihnya di diami oleh Suku Jawa, Padang, Batak dan lain-lain. Berdasarkan hasil data dari BPS Provinsi Aceh, berdasarkan tahun 2009-2015 jumlah penduduk wilayah Barat Selatan Provinsi Aceh untuk lebih jelasnya dapat dilihat pada tabel berikut:

Tabel 3. Jumlah Penduduk Wilayah Barat Selatan Provinsi Aceh berdasarkan Tahun 20092015.

\begin{tabular}{|c|r|r|r|r|r|}
\hline \multirow{2}{*}{ Tahun } & \multicolumn{5}{|c|}{ Kabupaten (Jiwa) } \\
\cline { 2 - 6 } & Aceh Jaya & Nagan Raya & Aceh Barat & Aceh Barat Daya & Aceh Selatan \\
\hline 2009 & 81054 & 125425 & 184147 & 130421 & 211564 \\
\hline 2010 & 77227 & 139663 & 173558 & 126705 & 204667 \\
\hline 2011 & 78540 & 142861 & 177532 & 144787 & 207025 \\
\hline 2012 & 82172 & 152130 & 182364 & 147924 & 208002 \\
\hline 2013 & 85908 & 158956 & 187459 & 150910 & 210071 \\
\hline 2014 & 86123 & 162448 & 190244 & 138140 & 220971 \\
\hline 2015 & 86385 & 155070 & 193791 & 140689 & 224897 \\
\hline Rata-rata & 82487 & 148079 & 184156,43 & 139939,43 & 2456,71 \\
\hline
\end{tabular}

Sumber: BPS Provinsi Aceh tahun 2010-2015(diolah) tahun 2017

Berdasarkan data di atas rata-rata jumlah penduduk tertinggi terdapat di Kabupaten Aceh Selatan dengan total 212456,71 jiwa. Sedangkan jumlah penduduk terrendah terdapat di Kabupaten Aceh Jaya dengan rata-rata jumlah penduduk sebesar 82487 jiwa. Hal ini di karenakan Kabupaten Aceh Jaya merupakan wilayah yang terkena dampak bencana Tsunami yang meluluhlantakkan sebahagian besar wilayahnya pada tahun 2004.

\section{Pertumbuhan Ekonomi Wilayah}

Pertumbuhan ekonomi wilayah merupakan realisasi hasil pembangunan ekonomi yang dilaksanakan pada suatu daerah dalam suatu periode. Gambaran kinerja perekonomian di kabupaten Nagan Raya dapat dilihat dari perkembangan Produk Domestik Regional Bruto 
(PDRB). Fluktuasi laju pertumbuhan ekonomi secara riil periode 2011-2015 di Kabupaten Nagan Raya dapat dilihat melalui penyajian laju pertumbuhan PDRB atas dasar harga konstan.

Tabel 4. Laju Pertumbuhan PDRB dalam Persen (\%) Menurut Lapangan Usaha Tahun 20132015 Tanpa Kabupaten Singkil, Kabupaten Simeulu dan Kota Subulussalam Atas Dasar Harga Konstan 2010

\begin{tabular}{|c|l|r|r|r|r|}
\hline \multirow{2}{*}{ No. } & \multicolumn{2}{|c|}{ Kabupaten } & \multicolumn{5}{|c|}{ Persen $(\%)$} \\
\cline { 3 - 6 } & & 2013 & 2014 & 2015 & Rata-Rata \\
\hline 1. & Aceh Jaya & 3,2 & 3,81 & 4,10 & 3,70 \\
\hline 2. & Nagan Raya & 3,4 & 2,95 & 3,89 & 3,41 \\
\hline 3. & Aceh Barat & 3,9 & 3,5 & 4,26 & 3,89 \\
\hline 4. & Aceh Barat Daya & 2,33 & 1,08 & 3,34 & 2,25 \\
\hline 5. & Aceh Selatan & 5,32 & 4,6 & 4,25 & 4,72 \\
\hline
\end{tabular}

Sumber: BPS Provinsi Aceh tahun 2013-2015 (diolah) tahun 2017

Dari tabel di atas dapat dilihat bahwa pada tahun terakhir di 5 kabupaten yang di teliti kabupaten yang memiliki rata-rata laju pertumbuhan yang tertinggi di wilayah penelitian yaitu Kabupaten Aceh Selatan yaitu sebesar 4,72\%. Sedangkan, kabupaten yang memiliki rata-rata tingkat laju pertumbuhan yang paling rendah diantara kelima kabupaten lainnya yaitu Kabupaten Aceh Barat Daya dengan nilai pertumbuhan sebesar 2,25\%. Hal ini dikarenakan pertumbuhan ekonomi Kabupaten Aceh Barat Daya mengalami fluktuasi pada tahun 2014 yaitu sebesar 1,08 sehingga rata-rata pertumbuhannya rendah dibandingkan dengan rata-rata pertumbuhan ekonomi di 2 kabupaten lainnya dalam penilitian.

\section{Kontribusi Sektor Industri Masing-Masing Wilayah Terhadap PDRB}

Sektor industri merupakan salah satu sektor yang berperan dalam meningkatkan pertumbuhan ekonomi daerah. Sektor industri yang terdapat di masing-masing wilayah barat selatan Provinsi Aceh ini terdiri dari beberapa industri rumahan seperti industri pengolahan makanan, minuman sampai dengan industri besar seperti industri perkebunan kelapa sawit. Peran sektor industri dalam pertumbuhan ekonomi menurut Arsyat (2010), bahwa sektor industri mempunyai peranan sebagai Leading Sector atau sektor pemimpin yang dimaksudkan dengan adanya pembangunan sektor industri akan memacu dan mengangkat sektor-sektor lainnya seperti sektor pertanian dan jasa. Hal ini berpengaruh terhadap peningkatan pertumbuhan masing-masing wilayah tersebut. Berikut merupakan kontribusi sektor industri terhadap PDRB tahun 2009-2015:

Tabel 5. Kontribusi Sektor Industri Terhadap PDRB Tahun 2009-2015 Atas Dasar Harga Konstan 2010.

\begin{tabular}{|c|c|r|r|r|r|r|}
\hline \multirow{2}{*}{ No. } & \multirow{2}{*}{ Tahun } & \multicolumn{5}{|c|}{ Kontribusi Industri Terhadap PDRB ( Juta Rupiah) } \\
\cline { 3 - 7 } & & Aceh Jaya & Aceh Barat & Nagan Raya & Aceh Barat Daya & \multicolumn{1}{c|}{ Aceh Selatan } \\
\hline 1. & 2009 & $22.808,97$ & $19.585,83$ & $29.995,82$ & $26.112,06$ & $62.379,48$ \\
\hline 2. & 2010 & $23.566,57$ & $21.504,97$ & $30.840,29$ & $27.046,75$ & $64.118,68$ \\
\hline 3. & 2011 & $24.121,22$ & $23.593,52$ & $32.594,10$ & $27.931,65$ & $64.865,78$ \\
\hline 4. & 2012 & $47.589,65$ & $75.158,24$ & $107.733,19$ & $62.068,60$ & $122.406,83$ \\
\hline 5. & 2013 & $49.814,35$ & $80.078,20$ & $113.998,95$ & $64.620,00$ & $127.997,51$ \\
\hline 6. & 2014 & $52.426,46$ & $83.746,19$ & $121.540,73$ & $67.091,80$ & $140.386,07$ \\
\hline 7. & 2015 & $55.106,04$ & $85.159,69$ & $123.467,39$ & $69.754,80$ & $147.486,19$ \\
\hline
\end{tabular}

Sumber: BPS Aceh Jaya, Aceh Barat, Nagan Raya, Aceh Barat Daya, Aceh Selatan Tahun 2009-2015.

Analisis Dampak Ketimpangan Pertumbuhan Ekonomi Wilayah Terhadap Kemiskinan Di Wilayah Barat 
Tabel di atas memperlihatkan jumlah kontribusi sektor industri yang terdapat di 5 kabupaten Barat Selatan Provinsi Aceh pada tahun 2009 sampai dengan tahun 2015. Jumlah kontribusi sektor industri yang paling besar terdapat di Kabupaten Aceh Selatan selama periode 7 tahun masa penelitian yaitu sebesar Rp. 147.486,19 ratus juta pada tahun 2015 . Sedangkan kontribusi sektor industri terendah terdapat di Kabupaten Aceh Jaya dengan total kontribusi sebesar Rp.55.106,04 juta. Kabupaten Nagan Raya merupakan kabupaten yang memiliki jumlah kontribusi terbesar ke 2 dan kotribusi terbesar ke 3 terdapat di Kabupaten Aceh Barat, sedangkan kontribusi sektor industri terbesar ke 4 terdapat di Kabupaten Aceh Barat Daya.

\section{Pendapatan Perkapita}

Pendapatan perkapita atau PDRB (Produk Domestik Regional Bruto) per kapita, yaitu perhitungan PDRB di suatu kabupaten/kota dibagi oleh populasi kabupaten/kota tersebut. Formulasi untuk menghitung pendapatan per kapita adalah:

$$
\text { Pendapatan Perkapita }=\frac{\text { Nilai PDRB Kabupaten } / \text { Kota }}{\text { Jumlah Penduduk Kabupaten } / \text { Kota }}
$$

Hasil yang di peroleh dari perhitungan di atas dapat dilihat pada tabel berikut:

Tabel 6. Pendapatan Perkapita masing-masing Kabupaten di Bagian Barat Provinsi Aceh tahun 2009-2015.

\begin{tabular}{|c|c|c|c|c|c|c|c|c|c|}
\hline \multirow[t]{2}{*}{ No. } & \multirow{2}{*}{$\begin{array}{c}\text { Nama } \\
\text { Kabupaten }\end{array}$} & \multicolumn{7}{|c|}{ Pendapatan Perkapita (Juta Rupiah) } & \multirow[t]{2}{*}{ Rata-rata } \\
\hline & & 2009 & 2010 & 2011 & 2012 & 2013 & 2014 & 2015 & \\
\hline 1. & Aceh Jaya & 3,268 & 18,426 & 18,872 & 18,757 & 18,515 & 19,173 & 19,898 & 16,701 \\
\hline 2. & Aceh Barat & 6,505 & 25,709 & 25,737 & 25,194 & 25,465 & 25,971 & 26,582 & 23,023 \\
\hline 3. & Nagan Raya & 7,412 & 32,749 & 32,854 & 31,994 & 31,661 & 31,894 & 34,711 & 29,039 \\
\hline 4. & $\begin{array}{l}\text { Aceh Barat } \\
\text { Daya }\end{array}$ & 4,869 & 17,655 & 15,907 & 15,867 & 15,916 & 17,575 & 17,833 & 15,089 \\
\hline 5. & Aceh Selatan & 5,902 & 13,830 & 14,267 & 14,979 & 15,620 & 15,532 & 15,909 & 13,720 \\
\hline
\end{tabular}

Sumber: BPS Provinsi Aceh tahun 2016 (diolah) tahun 2017

Tabel di atas memperlihatkan rata-rata pendapatan perkapita tertinggi selama 7 tahu terakhi masa penelitian terdapat di Kabupaten Nagan Raya yaitu sebesar Rp. 29,023 juta dan di susul oleh Kabupaten Aceh Barat yaitu sebesar Rp. 23,023 juta. Sedangkan pendapatan perkapita terendah terdapat di Kabupaten Aceh Selatan dengan rata-rata total pendapatan yaitu Rp.13,720 juta.

\section{Ketimpangan Pertumbuhan Ekonomi di Wilayah Barat Selatan Aceh.}

Indeks Williamson merupakan salah satu indeks yang paling sering digunakan dalam mengukur ketimpangan antar wilayah (Todaro, 2006). Indeks Williamson ini digunakan untuk mendeskripsikan ketimpangan wilayah dengan menggunakan nilai PDRB per kapita. Nilai yang di gunakan dalam indeks Williamson yaitu, 0 sampai dengan 1. Jika analisis menghasilkan nilai indeks di bawan 0,35 atau mendekati 0 berarti pertumbuhan ekonomi di wilayah tersebut merata, apabila nilai indeks Williamson antara 0,35 sampaidengan 0,50 berarti ketimpangan pertumbuhan ekonomi di wilayah tesebut tergolong sedang dan apabila indeks Williamson di atas 0,50 sampai dengan 1 berarti wilayah tersebut mengalami 
ketimpangan pertumbuhan ekonomi yang tinggi. Semakin besar indeks yang dihasilkan maka semakin besar tingkat ketimpangan pertumbuhan ekonomi antar wilayah di Kabupaten Nagan Raya. Hasil analisis yang dilakukan pada tahun penelitian menggunakan rumus indeks Williamson yang berorientasi pada PDRB perkapita dapat di lihat pada grafik berikut:

Tabel 7. Tingkat Ketimpangan Wilayah Perkabupaten di Barat Selatan Provinsi Aceh Tahun 2009-2015.

\begin{tabular}{|c|c|c|c|c|c|c|}
\hline \multirow{2}{*}{ No. } & \multirow{2}{*}{ Tahun } & \multicolumn{5}{|c|}{ Kabupaten } \\
\cline { 3 - 7 } & & Aceh Jaya & Nagan Raya & Aceh Barat & Aceh Barat Daya & Aceh Selatan \\
\hline 1. & 2009 & 0,35 & 0,3 & 0,38 & 0,38 & 0,37 \\
\hline 2. & 2010 & 0,3 & 0,52 & 0,38 & 0,55 & 0,37 \\
\hline 3. & 2011 & 0,44 & 0,3 & 0,55 & 0,88 & 0,39 \\
\hline 4. & 2012 & 0,3 & 0,34 & 0,55 & 0,55 & 0,42 \\
\hline 5. & 2013 & 0,35 & 0,37 & 0,66 & 0,88 & 0,41 \\
\hline 6. & 2014 & 0,5 & 0,4 & 0,38 & 0,5 & 0,42 \\
\hline 7. & 2015 & 0,55 & 0,4 & 0,39 & 0,62 & 0,5 \\
\hline \multicolumn{2}{|r}{ Rata-rata } & 0,40 & 0,38 & 0,47 & 0,62 & 0,41 \\
\hline
\end{tabular}

Sumber: BPS Provinsi Aceh tahun 2010-2016, ( diolah ) 2017

Berdasarkan tabel di atas, menunjukan ketimpangan yang ada di Wilayah Barat Selatan Provinsi Aceh tergolong sedang dan tinggi. Rata-rata ketimpangan tertinggi pada tahun penelitian terdapat di Kabupaten Aceh Barat Daya yaitu sebesar 0,62. Sedangkan ratarata ketimpangan terendah terdapat di Kabupaten Nagan Raya dengan nilai sebesar 0,38 yang termasuk ke dalam kategori ketimpangan sedang. Ketimpangan tertinggi terdapat di Kabupaten Aceh Barat Daya yaitu pada tahun 2011 dantahun 2013 yaitu sebesar 0,88. Sedangkan ketimpangan terendah terdapat di Kabupaten Aceh Jaya pada tahun 2010 dengan indeks sebesar 0,30 dan Kabupaten Nagan Raya pada tahun 2009 yaitu sebesar 0,30. Tingginya ketimpangan pertumbuhan ekonomi yang terjadi di Kabupaten Aceh Barat Daya pada tahun penelitian di karenakan tingginya jumlah penduduk yang tidak di ikuti oleh pendapatan perkapita.

Hal ini sesuai dengan pendapat Adelman dan Morris (1973) dalam Arsyad (2010) yang mengemukakan faktor penyebab ketimpangan pendapatan yaitu pertambahan penduduk yang tinggi sehingga mengakibatkan menurunnya pendapatan per kapita di wilayah tersebut. Richardson (1991) dalam teori basis ekspor juga menyatakan bahwa ciri-ciri kematangan dalam daerah-daerah yang sudah lama berpendapatan tinggi dapat melambatkan kenaikan pendapatan per kapita di masa mendatang.

\section{Pengaruh Faktor-Faktor yang Mempengaruhi Ketimpangan Pertumbuhan Ekonomi Wilayah.}

Pengujian kesesuaian model dalam persamaan faktor-faktor yang mempengaruhi ketimpangan pertumbuhan ekonomi wilayah dengan menggunakan 2 variabel bebas yaitu variabel pertumbuhan penduduk dan kontribusi sektor industri serta variabel terikat yaitu indeks ketimpangan pertumbuhan ekonomi wilayah dalam tahun penelitian di masing-masing kabupaten sehingga di peroleh hasil sebagai berikut:

$$
\begin{aligned}
& Y=\beta_{0}+\beta_{1} X_{1}+\beta_{2} X_{2}+\varepsilon \\
& Y=0,351+-, 0000017 X 1+0,115 X 2+\varepsilon
\end{aligned}
$$


Tabel 8. Hasil Analisis Regresi Faktor-faktor yang Mempengaruhi Ketimpangan Pertumbuhan Ekonomi Di Wilayah Barat Selatan Provinsi Aceh.

\begin{tabular}{|c|c|c|c|c|c|c|}
\hline \multirow[b]{2}{*}{ No. } & \multicolumn{2}{|c|}{ Variabel } & \multirow{2}{*}{$\begin{array}{c}\text { Koefisien } \\
\text { Regresi }\end{array}$} & \multirow{2}{*}{$\begin{array}{c}\text { Koefisien } \\
\text { Beta }\end{array}$} & \multicolumn{2}{|c|}{ Pengujian } \\
\hline & Bebas & Terikat & & & $\mathrm{t}$ hitung & Sig t \\
\hline 1. & $\begin{array}{l}\mathrm{X} 1=\text { Kontribusi } \\
\text { Sektor Industri }\end{array}$ & \multirow{2}{*}{$\begin{aligned} \mathrm{Y}= & \mathrm{Iw} \\
& \text { Pertumbuhan } \\
& \text { Ekonomi } \\
& \text { Wilayah }\end{aligned}$} &,- 0000017 & $-0,443$ & $-3,039$ & 0,005 \\
\hline 2. & $\begin{array}{l}\mathrm{X} 2= \\
\text { Pertumbuhan } \\
\text { Penduduk }\end{array}$ & & 0,115 & 0,343 & 2,352 & 0,025 \\
\hline Kor & nta $=0,351$ & $\mathrm{R}=0,565$ & & $F_{\text {hitung }}=7,503$ & & \\
\hline
\end{tabular}

Sumber : Data BPS Provinsi Aceh tahun, 2016 (diolah) tahun 2017

Hasil persamaan regresi tersebut dapat dijelaskan secara terperinci bahwa nilai konstanta dari nilai regresi tersebut sebesar 0,351, nilai ini berarti bahwa kenaikan sebesar 0,351 terjadi jika ada pengaruh dari kontribusi sektor industri dan pertumbuhan penduduk antar wilayah. Koefisien regresi kontribusi sektor industri $\left(\mathrm{X}_{1}\right)$ adalah sebesar- ,0000017 yang berarti bahwa setiap kenaikan kontribusi sektor industri sebesar satu unit, maka akan menurunkan ketimpangan pertumbuhan ekonomi sebesar -,0000017 unit dengan asumsi variabel lain tetap. Koefisien regresi pertumbuhan penduduk $\left(\mathrm{X}_{2}\right)$ adalah sebesar 0,115 , mempunyai arti bahwa setiap kenaikan pertumbuhan penduduk sebesar satu persen maka akan meningkatkan ketimpangan pertumbuhan ekonomi sebesar 0,115 dengan asumsi variabel lain tetap. Besarnya koefisien beta untuk variabel pertumbuhan penduduk sebesar 0,343 koefisien beta variabel kontribusi sektor industri sebesar -0,443. Dari hasil tersebut dapat diketahui bahwa variabel pertumbuhan penduduk adalah faktor paling dominan yang berpengaruh terhadap ketimpangan pertumbuhan ekonomi wilayah di Wilayah Barat Selatan Provinsi Aceh.

Penggunaan ketimpangan pertumbuhan ekonomi tidak terlepas dari situasi ekonomi secara keseluruhan. Pertumbuhan ekonomi yang tinggi akan menyebabkan beberapa sektor ekonomi yang berperan tumbuh dengan cepat. Pertumbuhan sektor di dalam PDRB tersebut akan memilih pada lokasi yang strategis, sektor strategis dan usaha yang potensial menghasilkan margin ekonomi yang tinggi seperti sektor industri. Sehingga pemilik kapital atau yang mempunyai kawasan strategis dan akses strategis cenderung yang memperoleh pendapatan yang tinggi. Artinya pertumbuhan ekonomi di Wilayah Barat Selatan Provinsi Aceh cenderung mempunyai hubungan positif yang signifikan antara variabel pertumbuhan penduduk dan ketimpangan pertumbuhan ekonomi wilayah, dikarenakan jika semakin tinggi pertumbuhan penduduk maka akan meningkatkan ketimpangan pertumbuhan ekonomi wilayah. Sedangkan variabel kontribusi sektor industri secara signifikan yang negatif akan mengurangi ketimpangan pertumbuhan ekonomi di Wilayah Barat Selatan Provinsi Aceh.

\section{Hubungan Antara Ketimpangan Pertumbuhan Ekonomi Wilayah Terhadap Kemiskinan}

Kemiskinan merupakan suatu permasalahan yang kompleks, kemiskinan bukan hanya masalah yang terjadi di negara berkembang seperti Indonesia, tetapi kemiskinan merupakan masalah dunia. Kemiskinan hampir dihadapi oleh seluruh negara baik negara maju maupun negara berkembang. Berdasarkan data yang di peroleh dari BPS Aceh dapat dilihat pada tabel berikut: 
Tabel 9. Persentase Jumlah Penduduk Miskin di Wilayah BaratSelatan Aceh

\begin{tabular}{|c|l|r|r|r|r|r|r|r|r|}
\hline \multirow{2}{*}{ No. } & \multirow{2}{*}{ Kabupaten } & \multicolumn{6}{|c|}{ Persentase Jumlah Penduduk Miskin } & \multirow{2}{*}{ Rata-rata } \\
\cline { 3 - 8 } & & 2009 & 2010 & 2011 & 2012 & 2013 & 2014 & 2015 & \\
\hline 1. & Aceh Jaya & 20,64 & 20,2 & 19,81 & 18,3 & 17,53 & 16,52 & 15,93 & 18,42 \\
\hline 2. & Nagan Raya & 23,22 & 23,07 & 22,38 & 21,27 & 20,75 & 19,85 & 18,13 & 21,24 \\
\hline 3. & Aceh Barat & 27,09 & 24,43 & 23,81 & 22,76 & 23,7 & 22,97 & 21,46 & 23,75 \\
\hline 4. & AcehBarat Daya & 27,33 & 26,93 & 25,49 & 24,51 & 23,92 & 22,99 & 21,20 & 24,62 \\
\hline 5. & Aceh Selatan & 17,88 & 16,79 & 15,64 & 14,80 & 13,44 & 12,79 & 13,24 & 14,94 \\
\hline
\end{tabular}
Sumber: BPS Provinsi Aceh tahun 2009-2016(diolah) tahun 2017

Hasil data BPS Provinsi Aceh, Wilayah Barat Selatan Provinsi Aceh berhasil menurunkan tingkat kemiskinan pada tahun 2009-2015. Walaupun demikian, Pemerintah Provinsi Aceh dan Pemerintah kabupaten harus tetap berusaha menurunkan angka kemiskinan sekecil-kecilnya. Jika dilihat dari jumlah persentase, angka rata-rata persentase penduduk miskin tertinggi terdapat di Kabupaten Aceh Barat dengan nilai 23,75\% sedangkan rara-rata persentase jumlah penduduk miskin terendah terdapat di Kabupaten Aceh Selatan. Pengaruh antara ketimpangan distribusi pendapatan terhadap kemiskinan dipengaruhi oleh adanya peningkatan jumlah penduduk, pertambahan penduduk cenderung berdampak negatif terhadap penduduk miskin terutama bagi mereka yang sangat miskin. Sebagian besar keluarga miskin memiliki jumlah anggota keluarga yang banyak sehingga kondisi perekonomian mereka yang berada di bawah garis kemiskinan semakin memburuk seiring dengan memburuknya ketimpangan pendapatan atau kesejahtera. Hubungan ketimpangan pertumbuhan ekonomi wilayah terhadap jumlah penduduk miskin yang ada di wilayah barat selatan di sajikan secara rata-rata 7 tahun masa penelitian dan di jelaskan secara deskriptif pada grafik berikut:

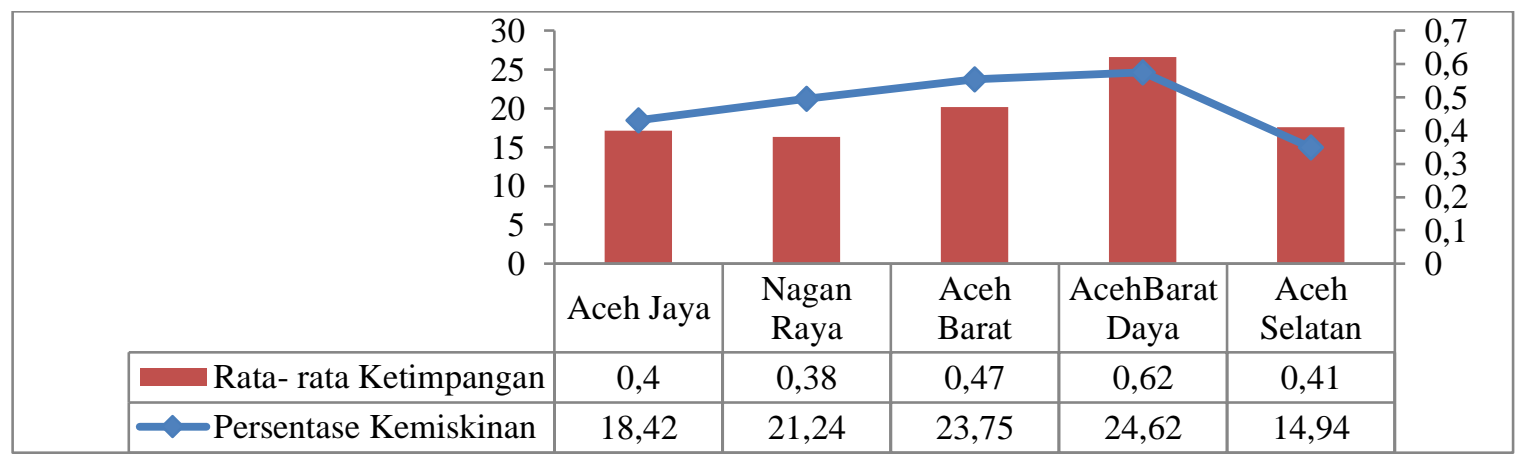

Sumber: BPS Provinsi Aceh Dalam Angka Tahun 2009-2015 (diolah) tahun 2017

Grafik 1. Deskripsi Hubungan Ketimpangan Pertumbuhan Ekonomi Wilayah dan Kemiskinan

Dari grafik diatas dapat dilihat garis hijau merupakan garis yang menggambarkan ratarata angka tingginya persentase penduduk miskin sedangkan garis balok merah menggambarkan indeks rata-rata ketimpangan pada tahun penelitian. Keterkaitan antara ketimpangan dengan kemiskinan, pertumbuhan ekonomi akan meningkatkan pendapatan ratarata di suatu wilayah. Salah satu penyebab dari kemiskinan adalah adanya ketidak samaan pola kepemilikan sumber daya masing-masing wilayah yang selanjutnya akan menimbulkan distribusi pendapatan yang timpang. 


\section{KESIMPULAN DAN SARAN}

Berdasarkan hasil analisis dapat disimpulkan bahwa:Rata indeks ketimpangan pertumbuhan ekonomi tergolong tinggi dengan indek sebesar 0,62 selama 7 tahun masa penelitian (2009-2017). Ketimpangan terjadi di Kabupaten Aceh Barat Daya.Faktor-faktor yang mempengaruhi ketimpangan pertumbuhan ekonomi wilayah di Wilayah Barat Selatan Provinsi Aceh yaitu faktor pertumbuhan penduduk secara positif mempengaruhi dan faktor kontribusi sektor industri memiliki pengaruh negatif yang signifikan. Dari hasil penelitian juga dapat di simpulkan bahwa semakin besar ketimpangan pertumbuhan ekonomi wilayah yang terjadi maka akan berdampak pada tingginya jumlah persentase kemiskinan yang ada di wilayah tersebut.

\section{DAFTAR PUSTAKA}

Arsyad, L. 2010. Pengantar Perencanaan dan Pembangunan Ekonomi Daerah. Yogyakarta: BPFE.

Badan Pusat Statistik. 2008-2015. Aceh Dalam Angka. BPS Provinsi Aceh. Banda Aceh.

Badan Pusat Statistik Nagan Raya. 2014. Nagan Raya Dalam Angka. BPS Kabupaten Nagan Raya. Suka Makmur.

Badan Pusat Statistik Nagan Raya. 2015. Nagan Raya Dalam Angka. BPS Kabupaten Nagan Raya. Suka Makmur.

Ginting Ari Mulyanta. (2013). Pengaruh Pertumbuhan Ekonomi dan Pertumbuhan Sektor Sektor Keuangan terhadap Pengurangan Kemiskinan di Indonesia, Jurnal Ekonomi dan Kebijakan Publik, No. 1(2).

Gujarati. D. 1978. Ekonometrika Dasar. Penerbit Erlangga. Jakarta.

Harlik. 2013. Faktor-faktor Yang Mempengaruhi Kemiskinan dan Pengangguran di Kota Jambi. Jurnal Perspektif Pembiayaan dan Pembangunan Daerah Vol. 1 No. 2, hal. 02. Oktober 2013.

Matolla, A. A. 1985. Peranan Sektor Pertanian Terhadap Peningkatan Dan Pemerataan Pendapatan Daerah di Jawa Barat .(Tesis). Program Perencanaan Wilayah Dan Kota, Fakultas Pasca Sarjana, Instiut Teknologi Bandung, Bandung.

Mopangga. 2011. Analisis Ketimpangan Pembangunan dan Pertumbuhan Ekonomi di Provinsi Gorontalo. Jurnal Trikonomika. Vol. 10. No. 2.

Nurhuda, Rama., Muluk, Khairul., \& Prasetyo, Wima Yudo. (2012). Analisis KetimpanganPembangunan (Studi di Provinsi Jawa Timur 2005-2011). Jurnal Administrasi Publik, Vol. 1 No. 4. Sadono, Sukirno. 1985. Ekonomi Pembangunan, Penerbit FEUI.

Pamrihnan. A. 2016. Analisis Ketimpangan Pendapaten dan Indentifikasi Sektor Basis Antar Kecamatan Di Kabupaten Wonogiri tahun 2010- 2014. Jurnal Vol. 19. No. 2 ISSN (P) 1412-2200 E- ISSN 2548-1451.

Pauji Ahmad. 2016. Faktor-faktor yang mempengaruhi Secara Langsung Maupun Tidak Langsung Ketimpangan Distribusi Pendapatan Provinsi Bali. Jurnal Ekonomi Pembangunan Universitas Udayana. VOL.5, NO. 6.

Sugianto, FX. 2013. Pengaruh Pertumbuhan Ekonomi, Share Sektor Industri dan Pertanian Serta Tingkat Jumlah Orang Yang Bekerja Terhadap Ketimpangan Wilayah Antar Kabupaten/Kota di Jawa Tengah Tahun 2002-2010. Diponegoro Journal Of Ekonomics Volume 2, Nomor 1, Tahun 2013, Halaman 1 - 14.

Analisis Dampak Ketimpangan Pertumbuhan Ekonomi Wilayah Terhadap Kemiskinan Di Wilayah Barat 
Sukirno, Sadono. 2004. Ekonomi Pembangunan, Proses, Masalah dan Dasar Kebijakan. Edisi kedua. Kencana Preda Media Group. Jakarta

Todaro, M. P. 2000. Pembangunan Ekonomi Dunia Ketiga. Jilid 1, Edisi Keenam. Erlangga. Jakarta.

Todaro M.P. 2006. Pembangunan Ekonomi Dunia Ketiga. Edisi ketujuh. Erlangga, Jakarta

Umiyati Etik. 2013. Analisa Pertumbuhan Ekonomi dan Ketimpangan Pembangunan Antar Wilayah Di Pulau Sumatera. Jurnal Paradikma Ekonomika Vol. 1. No. 7. April 2013 Hal. 49.

Williamson, J. G. 1965. Regional and Equality and The Process of National Development; A Description of Pattern. Economic Development and Cultural Change, Vol.13, No. 4, Hal 3-45. 